\title{
PKM wt Allele
}

National Cancer Institute

\section{Source}

National Cancer Institute. PKM wt Allele. NCI Thesaurus. Code C74442.

Human PKM wild-type allele is located in the vicinity of $15 \mathrm{q} 23$ and is approximately $33 \mathrm{~kb}$ in length. This allele, which encodes pyruvate kinase PKM protein, plays a role in the progression of glycolysis. Aberrant expression of the M2 isoform of the gene may be involved in the regulation of cancer cell growth and proliferation. 